\title{
MARINE PLASTIC LITTERING: A REVIEW OF SOCIO ECONOMIC IMPACTS
}

\author{
ELENI ARETOULAKI, STAVROS PONIS*, GEORGE PLAKAS AND KOSTANTINOS \\ AGALIANOS
}

National Technical University Athens, Heroon Polytechniou 9, Zografos 15780, Athens, Greece.

*Corresponding author: staponis@central.ntua.gr

Submitted final draft: 27 April $2020 \quad$ Accepted: 4 July $2020 \quad$ http://doi.org/10.46754/jssm.2021.04.019

\begin{abstract}
Marine plastic littering resulting from human activity constitutes an increasingly significant global issue. The use of plastic materials is steadily rising due to their light weight, durability and versatility. However, they are also low cost, leading to a higher chance of them being disposed of and consequently ending up in the marine environment. Furthermore, their low decomposition rates as a consequence of the aforementioned properties, result in plastic accumulation. This paper reviews marine plastic pollution and highlights the progress of research on its socioeconomic consequences, within the scope of ultimately developing a marine sustainability and protection approach. To that end and after a systematic inclusion/exclusion process of publications retrieved from the Scopus and Google Scholar bibliographic databases, six hundred and sixty-six (616) papers were selected for participation in the study. As far as economic implications are concerned, the impact of marine plastic pollution on marine-based sources of income, such as fishing, aquaculture, marine tourism and merchant shipping, was studied. Next, this paper evaluates the dire social repercussions in terms of human food safety and health, threat of injury or death and intrinsic natural value loss. Finally, prevention measures in the form of legislation and coping strategies at an international level are discussed.
\end{abstract}

Keywords: Marine plastic littering, socioeconomic impact, marine sustainability, microplastics.

\section{Introduction}

Marine pollution is attributed to anthropogenic activities and the abundance of chemical substances involved. According to global data, 63,000 chemicals are currently used by industries, with 3,000 of them accounting for $90 \%$ of world production. At the same time, about a thousand new synthetic substances are added to the world market each year (Belgian Platform on Earth Observation, 2009). For instance, it has been calculated that 275 million tons of plastic substances were generated in 192 coastal countries in $2010,1.7$ to $4.6 \%$ of which (4.8 to 12.7 million tons) ended up in the ocean (Jambeck et al., 2015). At the same time, marine plastic pollution in the environment is anticipated to escalate, since the production of plastics has been increasing, reaching almost 360 million tons in 2018 (Plastics Europe, 2019).

Eutrophication of water, where excessive amounts of nutrients are introduced to aquatic environments,is a very serious form of pollution, resulting in oxygen depletion with significant repercussions for drinking water sources, fisheries and recreational water bodies (Chislock et al., 2013). Water contamination as a result of the multiplication of pathogenic microorganisms (e.g. bacteria, protozoa, viruses), increases the likelihood of transmission of diseases and hence, poses a major risk in water resources (Pandey et al., 2014). Last but not least, bioaccumulation due to persistent organic pollutants (POPs) (Langenbach, 2013), heavy metals (Bawuro et al., 2018), oils (Almeda et al., 2013) and radioactive detritus (Davis \& Foster, 1958), leading to chronic poisoning, are merely a few examples of marine pollution. Nevertheless, plastic debris seems to be posing the greatest threat to the marine environment, since more than $80 \%$ of marine pollution originates from plastics (Moore, 2008). 
As already stated, marine plastic litter has been rapidly increasing in recent decades and does not appear to show signs of receding. Production of new plastics, reached 90 million tonnes in 1985 , and increased to 380 million tonnes in 2015 (Geyer et al., 2017).hile from 1950 to 2015 , plastic production cumulatively exceeded 8.3 billion tonnes, half of which was produced after 2004 (Mortillaro, 2017). Plastics are indispensable, omnipresent materials in contemporary society and one of the world's influential industrial inventions. Their light weight, durability and versatility are benefits reflected in plastic production (Lee et al., 2017), which is being actively promoted by political and economic forces, with packaging accounting for about $40 \%$ of production, while retail products for 20-25\% (UNEP, 2016b; Worm et al., 2017). For instance, plastic bottle sales rose from $\$ 300$ billion in 2004 to $\$ 500$ billion in 2016 and are expected to reach $\$ 600$ billion by 2021 , as demand for bottled water is growing exponentially (Laville \& Taylor, 2017). In general, worldwide plastics consumption is anticipated to sharply increase, reaching approximately 400 million tonnes on a yearly basis by 2025 .

The amount of plastics ending up in the marine environment has been progressively increasing from eight million tonnes in 2010 to more than nine million tonnes in 2015 and is predicted to have exceeded 16 million tonnes by 2025 (Jambeck et al., 2015). Provided that the rate at which plastic debris infiltrating marine environments does not dwindle, it is likely that the world's oceans will contain one tonne of plastic for every three tonnes of fish by 2025 (MacArthur, 2016). Already, in 2012, marine plastic pollution is alleged to be equivalent to a plastic grocery bag thrown into the ocean per capita per week (Boucher \& Friot, 2017).

Surveys on the composition of waste in different marine areas indicated that plastics including petroleum-based synthetic materials constitute, as stated above, the largest proportion of total marine waste pollution (Pham et al., 2014). Packaging materials, fishing gear, as well as, small - difficult to identify - pieces of plastic, called microplastics, represent the majority of plastic waste (Galgani et al., 2013). Microplastics, either primary or secondary, are pieces of plastic, smaller than $5 \mathrm{~mm}$ (Betts, 2008; Barnes et al., 2009). The distinction between primary and secondary microplastics is based on whether the particles were originally intended to be a specific size (primary), such as the microbeads added to products like toothpaste (Bråte et al., 2018), face wash (Zitko \& Hanlon, 1991; Fendall \& Sewell, 2009), abrasive cleaners or paint (Verschoor, et al., 2016), or their size comes as a result from the fragmentation of larger plastic objects (secondary) (Efimova et al., 2018) due to ultraviolet (UV) photodegradation (Andrady et al., 2011) or mechanical abrasion (Barnes et al., 2009). Although, the durability of plastics leads to very low rates of degradation, if any, still the problem of microplastics remains critical since rapid plastic pollution leads to high accumulation of plastics, which even if removed at some point, the microplastics produced by the degradation of larger pieces are almost impossible to be traced and removed.

The prevalence of plastics and microplastics in the ocean, mostly on account of their size and recalcitrant nature has the potential to evoke multifaceted detrimental effects (Engler, 2012; Keswani et al., 2016; Barboza et al., 2018; Hahladakis et al., 2018; Haegerbaeumer et al., 2019). The present paper reviews the contemporary literature on the economic and social repercussions of plastics and microplastics, as well as the preventive measures and coping strategies towards marine sustainability.

\section{Methodology}

The evolving landscape of bibliometric data sources provides great opportunities for researchers to make academic progress in the field of marine plastic pollution. In our study, data on the retrieval of publications from the Scopus and Google Scholar databases were collected. Moreover, given the nature of the research topic, which captures the attention of both the academic community and a plethora 
of organisations fighting for environmental protection, relevant research outside of academia was included. In particular, the regulatory framework of the European Union (EU), the United Nations (UN) and the Organization for Economic Co-Operation and Development (OECD) repositories were studied as well as Non-Governmental Organization (NGO) actions and published research on the internet.

The keywords selected in this initial search of the available literature were: 1) "marine pollution", 2) "marine litter*", 3) "sea pollution", 4) "sea litter*", 5) "global marine litter*”, 6) "global marine pollution", 7) "plastic marine litter*", 8) "plastic marine pollution". The Boolean operator "OR" was applied to achieve different keyword combinations.

Approximately $12 \%$ of the results yielded from this initial search were published prior to the year 2000. Nevertheless, their center of focus was mainly the pollution of the marine environment from oil spills, pathogenic microorganisms and shipwrecks. As a consequence, it was decided to limit the time range from 2000 to the present, hence, excluding the aforementioned papers. Another reason behind this decision was also the scientific community's recent interest in environmentalrelated marine plastic pollution(Stefatos et al., 1999).

The search fields selected in this research were the 'Title', 'Abstract' and 'Keywords' of each publication. Scopus enables simultaneous search in all three of these fields through the "Article Title, Abstract, Keyword" option. Google Scholar, however, provides only two search options, based on a) Title or b) Fulltext. In this case, the search was limited to the title of each publication, as looking for keywords in the full text would return an unmanageable number of results and derail this study. As for the document type, the main categories of publications included in the study are the following: a) Articles in peer-reviewed journals presenting results of national as well as international research (Journal Papers), b) Review papers in peer-reviewed journals and c)
Book chapters and edited volumes. It is worth noting that Google Scholar does not provide filtering functionality based on the document type of publications.

Last but not least, the final step of this process was the selection of publications' subject area, as defined by their author. The topic of marine pollution has been researched by scientists across many disciplines, with specializations in economics, pharmaceuticals, supply chains, computing, etc. In this review, we ensured that at least one of the research areas of each publication would fall into the subject category of "Environmental Science". Thus, the output would turn out to be more relevant to the subject under consideration without omitting any contributions from other scientific fields with respect to this major environmental problem. It is worth mentioning again that Google Scholar does not provide a filtering option based on the subject area of research.

\section{Results}

The purpose of this review is to investigate the socioeconomic repercussions of marine plastic pollution, as well as preventive measures and coping mechanisms to mitigating the situation. The application of the aforementioned inclusion and exclusion criteria resulted in 616 papers being selected for this study. Our analysis shows that there are 10 scientific journals with 10 or more publications in the initial sample, as shown in Figure 1. It has to be noted that one journal, i.e. the "Marine Pollution Bulletin" is responsible for $25 \%$ of the publications included in this study.

By reading carefully the abstracts of all retrieved papers, the authors identified and taxonomized the sample in five thematic areas: (a) composition and distribution of Marine Pollution; (b) sources of Marine Pollution; (c) socioeconomic impact of Marine Pollution; (d) regulatory framework and management of Marine Pollution; and, (e) Plastic Marine Pollution. The last category applies to all sizes of plastic waste ranging from macroplastics 


\begin{tabular}{|l|l|}
\hline Scientific Journal & Number of Publications \\
\hline Marine Pollution Bulletin & 154 \\
\hline Science of the Total Environment & 33 \\
\hline Environment International & 23 \\
\hline Environmental Pollution & 19 \\
\hline $\begin{array}{l}\text { Environmental Science and } \\
\text { Technology }\end{array}$ & 15 \\
\hline Marine Environmental Research & 14 \\
\hline Ocean and Coastal Management & 13 \\
\hline Water Environment Research & 11 \\
\hline Ecotoxicology & 11 \\
\hline $\begin{array}{l}\text { Environmental Toxicology and } \\
\text { Chemistry }\end{array}$ & 10 \\
\hline
\end{tabular}

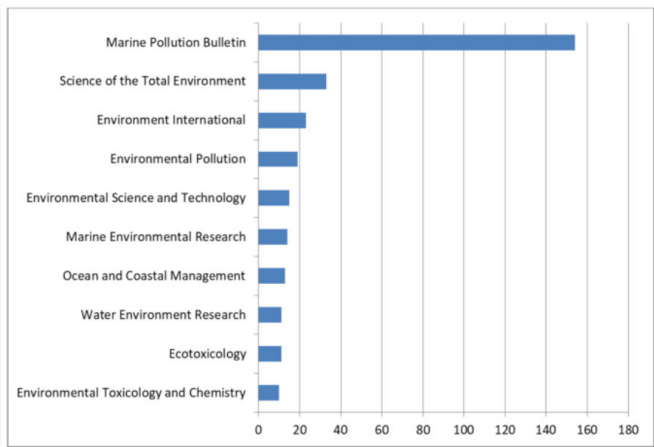

Figure 1: List of scientific journals with more than ten publications

(>25mm)(Hammer et al., 2012) and mesoplastics ( $>5 \mathrm{~mm})$ (Lee et al., 2009), to micro- $(>0.1 \mathrm{~mm})$ or nano- $(<100 \mathrm{~nm})$ scale plastic particles (Alimi et al., 2018). However, all plastic particles smaller than $5 \mathrm{~mm}$, henceforth, will be referred to as microplastics for the sake of simplicity.

As anticipated, a large percentage of the articles belonged to more than one of the identified thematic areas, while exactly half of the publications were deemed as not relevant, since they could not be attributed to at least one of the aforementioned categories. The number of papers per thematic area are presented in Figure 2. This study, by its aforementioned prescription, focuses on the socioeconomic impact of marine plastic littering, i.e. on publications on the intersection of thematic areas (c), (d) and (e).
Eighty-nine publications fall in the third thematic area - the social and economic implications of marine pollution. Of this number, $20.22 \%$ (18 publications) referred to plastic marine littering in general and $14.61 \%$ (13 publications) to microplastics in particular. Respectively, the corresponding percentages for the fourth thematic area amounted to $31.37 \%$ (16 publications) and $23.53 \%$ (12 publications) (Figure 3). Furthermore, it is worth noting the unequal distribution of papers between social (73 publications) and economic (16 publications) impact, with the former exceeding the latter by 57 papers (Figure 4). All these findings are summarized in the following bar graphs.

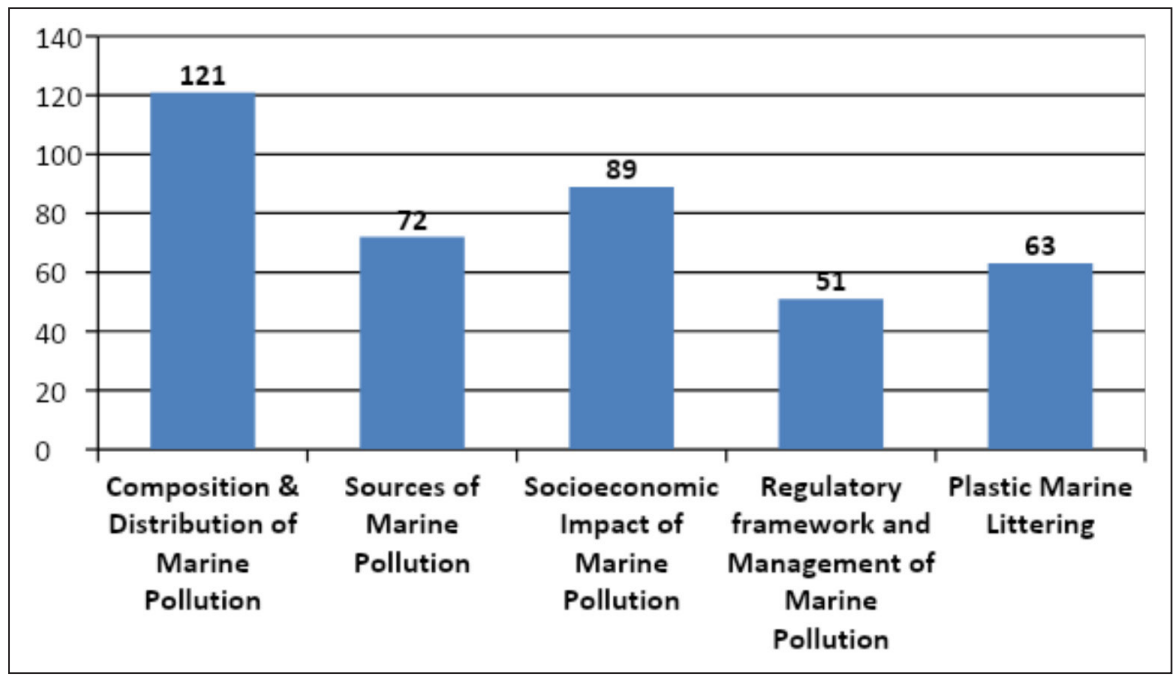

Figure 2: Number of publications per thematic area 


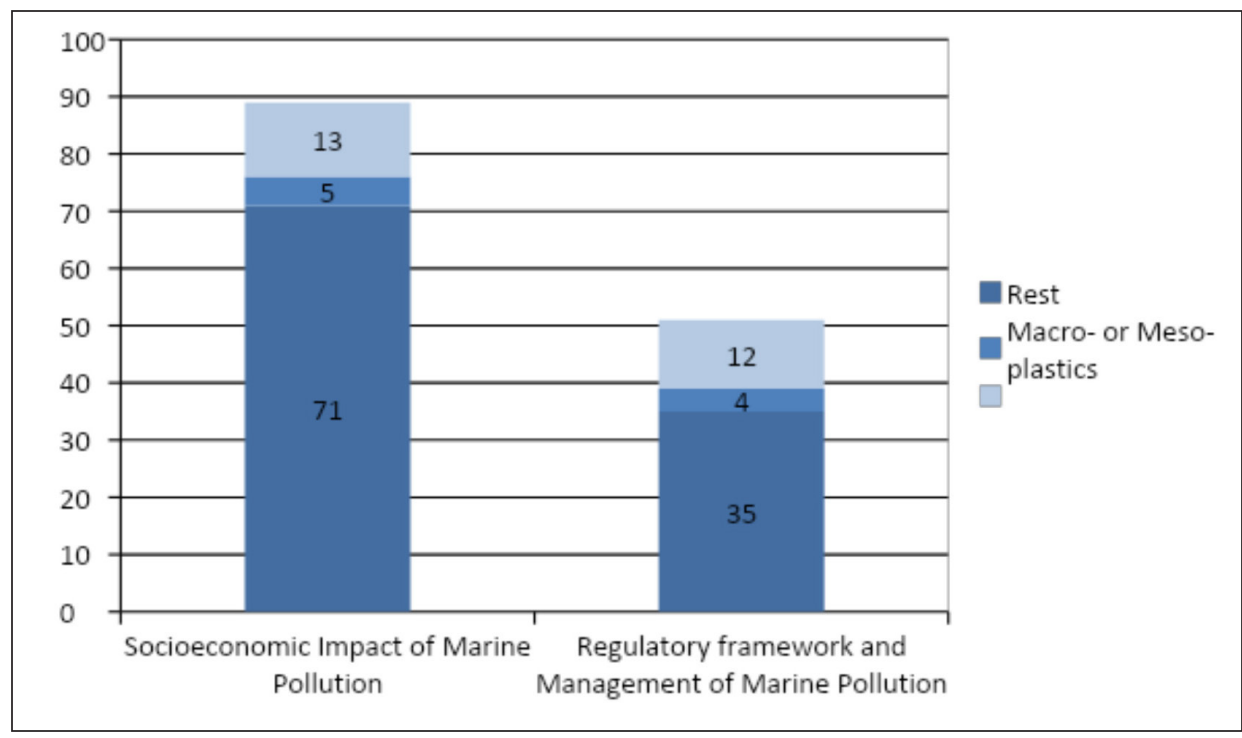

Figure 3: Number of publications: socioeconomic impact vs. regulatory framework and marine pollution management

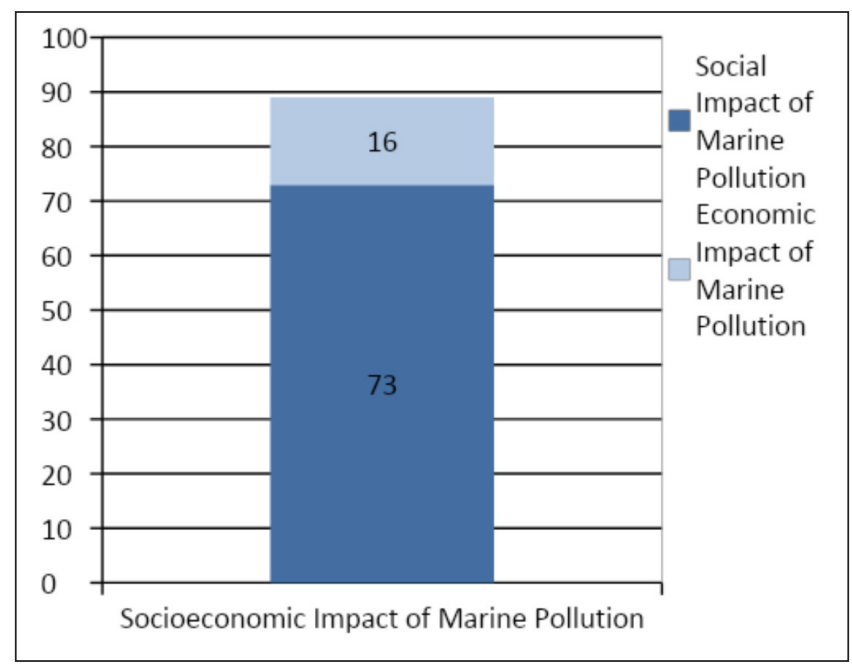

Figure 4: Number of publications: social vs. economic impact

\section{Discussion}

In the following sections, the economic and social impacts of marine plastic pollution are discussed, along with prevention efforts and coping mechanisms for accomplishing marine sustainability. In particular, economic impacts have been classified into three categories, which represent the most affected and, therefore, studied sectors (Carr, 2019), namely the seafood industry, tourism industry and shipping industry. Correspondingly, social impacts have been grouped into three categories as well. The first two categories pertain to human health and well-being, focusing respectively on human food security and threat of injury or death from marine plastic pollution. The third one gravitates towards the impact on cultural heritage and specifically refers to intrinsic natural value loss. 
In the end of each thematic category and in order to summarize its key points, a summary table is provided, presenting the references used in each section and a short but comprehensive description of the publication's core theme.

\section{Socioeconomic Impact}

According to the Organization for Economic Co-operation and Development (OECD), oceans add approximately $\$ 1.5$ trillion yearly in value to the global economy, supporting close to 40 million full-time jobs (OECD, 2016). The economic value of sea-based activities largely comprises interdependent industries, such as fishing, aquaculture, marine tourism and merchant shipping. It is evaluated that more than two thirds of the worldwide gross marine product depends on a healthy marine ecosystem, which is already under pressure (Hoegh-Guldberg, 2015). According to the United Nations Environment Assembly, marine debris costs approximately $\$ 13$ billion annually on a global scale (UN News, 2014), due to hindering maritime economic activities. Fishing and aquaculture contribute largely to economic growth on a worldwide scale. Recent official statistics demonstrate that, in 2016, 19.3 million people engaged in aquaculture, as opposed to fishing, which attracted 40.3 million people. Rising demand has abruptly increased the value of global fish exports, from $\$ 8$ billion in 1976, to $\$ 152$ billion in 2017 (Food and Agriculture Organization of the United Nations, 2018). However, plastic debris has turned out to be undermining the sectors' long-term prospects (Food and Agriculture Organization of the United Nations, 2018).

Profit from fishing and aquaculture is also affected by direct and indirect plastic marine pollution. The direct economic consequences include the cost of repairing damaged fishing vessels and aquaculture facilities (Iñiguez et al., 2016). The damage is mostly ascribable to plastic debris blocking cooling systems or entangling propellers (McIlgorm et al., 2011). Problems also arise from derelict nets entangling active nets. According to statistics from insurance companies in Japan, the cost of repairing damaged fishing vessels added up to $\$ 40$ million in 1985 , which is $0.3 \%$ of the country's total annual fishing revenue (Takehama, 1990). In the European Union, the total repairing cost amounted to $\$ 65.7$ million, representing $0.9 \%$ of the yearly fishing income (Mouat et al., 2010; Arcadis, 2014).

The indirect economic impact of marine plastic pollution on fishing and aquaculture derives from the decrease of fisheries resources due to ghost fishing (Sheppard, 2018). Aquatic commercial target species amongst other marine organisms get caught, injured or even killed by abandoned, lost or discarded fishing equipment, leading to calamitous effects on the conservation of susceptible marine fauna and the economy. Fish predators also run the risk of getting caught by derelict nets, wires and traps, while attempting to capture entangled fish, thus, perpetuating the problem (NOWPAP MERRAC, 2013).

Gilardi et al. demonstrated promising costbenefit analysis results (Gilardi et al., 2010). They showed that the retrieval of a derelict gill net costs $\$ 1,358$, but its abandonment resulted in $\$ 19,656$ in lost Dungeness crab, until the net completely decomposes (1:14.5 costbenefit ratio) (Sheppard, 2018). Scheld et al. estimated, using data from the Chesapeake Bay program, that the removal of 34,000 crab pots contributed to additional harvests of nine types of crustaceans, whose worth amounted to more than \$21 million (Scheld et al., 2016). In the Chesapeake Bay blue crab fishery, ghost gear captures nearly 900,000 animals every year, causing a potential $\$ 300,000$ in losses annually (Bilkovic et al., 2014).

To make matters worse, seafood demand, affecting both fishing and aquaculture, depends on consumers' trust in its quality. If consumers evaluate the presence of microplastics in seafood to be consumed as important, taking into consideration the risks involved, their behavior might fundamentally change, leading to reduction in seafood consumption, regardless of possible reassurance from scientists 
or authorities. This concern is reinforced by previous similar consumer reactions, concerning radioactive contamination of food following major accidents. It is evident that this could diminish the development opportunities of the seafood industry. Finally, one should not overlook the impact of microplastics to the reported health or reproductive capacity exacerbation of organisms leading to reduced seafood supply and quality, thus increasing the cost of wastage and quality control. .

Table 1: Economic Impacts on the Seafood Industry

\begin{tabular}{|c|c|c|}
\hline Author, Year & Title & Description \\
\hline OECD, 2016 & The trillion dollar ocean & $\begin{array}{l}\text { The paper discusses the expected economic growth of } \\
\text { ocean-based industries. }\end{array}$ \\
\hline $\begin{array}{l}\text { Hoegh-Guldberg, } \\
2015\end{array}$ & $\begin{array}{l}\text { Reviving the Ocean } \\
\text { Economy: the case for } \\
\text { action }\end{array}$ & $\begin{array}{l}\text { The paper analyses the ocean's role as an economic } \\
\text { powerhouse and outlines the threats that are moving it } \\
\text { towards collapse. }\end{array}$ \\
\hline UN News, 2014 & $\begin{array}{l}\text { Plastic waste causes } \$ 13 \\
\text { billion in annual damage } \\
\text { to marine ecosystems, says } \\
\text { UN agency }\end{array}$ & $\begin{array}{l}\text { The report sheds light on the negative financial impacts } \\
\text { of marine plastic pollution, as indicated by various } \\
\text { reports and books. }\end{array}$ \\
\hline $\begin{array}{l}\text { Food and } \\
\text { Agriculture } \\
\text { Organization } \\
\text { of the United } \\
\text { Nations, } 2018\end{array}$ & $\begin{array}{l}\text { The State of World } \\
\text { Fisheries and Aquaculture } \\
2018 \text { - Meeting the } \\
\text { sustainable development } \\
\text { goals }\end{array}$ & $\begin{array}{l}\text { The report highlights the critical importance of fisheries } \\
\text { and aquaculture for the food, nutrition and employment } \\
\text { of people. }\end{array}$ \\
\hline Iñiguez et al. 2016 & $\begin{array}{l}\text { Marine debris occurrence } \\
\text { and treatment: A review }\end{array}$ & $\begin{array}{l}\text { The paper addresses the environmental and social impact } \\
\text { of marine debris, with a review of its treatment, together } \\
\text { with an estimation of the worldwide occurrence and } \\
\text { characteristics. }\end{array}$ \\
\hline $\begin{array}{l}\text { McIlgorm et al. } \\
2011\end{array}$ & $\begin{array}{l}\text { The economic cost and } \\
\text { control of marine debris } \\
\text { damage in the Asia-Pacific } \\
\text { region }\end{array}$ & $\begin{array}{l}\text { The paper examines the economic costs associated } \\
\text { with marine debris and suggests a simple marine debris } \\
\text { cycle model. Next it discusses the costs and benefits of } \\
\text { prevention, clean-up and utilization of biodegradable } \\
\text { materials. }\end{array}$ \\
\hline Takehama, 1990 & $\begin{array}{l}\text { Estimation of damages to } \\
\text { fishing vessels caused by } \\
\text { marine debris, based on } \\
\text { insurance statistics }\end{array}$ & $\begin{array}{l}\text { The paper attempts an estimation of the number of } \\
\text { accidents and the amount of damage and losses of } \\
\text { fishing vessels caused by marine debris, based on } \\
\text { insurance statistics. }\end{array}$ \\
\hline Mouat et al. 2010; & $\begin{array}{l}\text { Economic Impacts of } \\
\text { marine litter }\end{array}$ & $\begin{array}{l}\text { This study addresses the economic impacts of marine } \\
\text { litter. }\end{array}$ \\
\hline Arcadis, 2014 & $\begin{array}{l}\text { Marine Litter study to } \\
\text { support the establishment } \\
\text { of an initial quantitative } \\
\text { headline reduction target }\end{array}$ & $\begin{array}{l}\text { This report summarizes the results of support given } \\
\text { to the European Commission on several topics related } \\
\text { to marine litter. The main scope is to support the } \\
\text { development of an EU headline marine litter reduction } \\
\text { target. }\end{array}$ \\
\hline
\end{tabular}




\begin{tabular}{lll}
\hline Sheppard, 2018 & $\begin{array}{l}\text { World Seas: An } \\
\text { Environmental Evaluation: } \\
\text { Volume III: Ecological } \\
\text { Issues and Environmental } \\
\text { Impacts }\end{array}$ & $\begin{array}{l}\text { This book covers global issues relating to our seas, } \\
\text { including a biological description of the coast and } \\
\text { continental shelf waters, the development and use } \\
\text { of the coast, landfills and their effects, pollutant } \\
\text { discharges over time, the effects of over-fishing, and } \\
\text { the management methods and techniques used to ensure } \\
\text { continued ecosystem functioning. }\end{array}$ \\
\hline NOWPAP & $\begin{array}{l}\text { Negative Impacts of } \\
\text { MERRAC, } 2013 \\
\text { NOWPAP Litter in the } \\
\text { Studies }\end{array}$ & $\begin{array}{l}\text { This report provides concrete evidence of how } \\
\text { communities are affected by marine litter through } \\
\text { selected case studies. A regional perspective is taken to } \\
\text { look at the environmental, social and economic impacts } \\
\text { of marine litter. }\end{array}$ \\
\hline Gilardi et al. 2010 & $\begin{array}{l}\text { Marine species mortality } \\
\text { in derelict fishing nets in } \\
\text { Puget Sound, WA, and the } \\
\text { cost/benefits of derelict net } \\
\text { removal }\end{array}$ & $\begin{array}{l}\text { This paper estimates the daily catch rate of a given } \\
\text { derelict gillnet and provides a model to predict expected } \\
\text { total mortality caused by a given fishing net. Also, it } \\
\text { suggests a cost-benefit ratio for derelict gear removal. }\end{array}$ \\
\hline Scheld et al. 2016 & $\begin{array}{l}\text { The dilemma of derelict } \\
\text { gear }\end{array}$ & $\begin{array}{l}\text { This paper presents and analyses the economic effects of } \\
\text { a substantial derelict pot removal program in the largest } \\
\text { estuary of the United States, Chesapeake Bay. }\end{array}$ \\
\hline Bilkovic et al. & $\begin{array}{l}\text { Derelict fishing gear in } \\
\text { Chesapeake Bay, Virginia: } \\
\text { Spatial patterns and } \\
\text { implications for marine } \\
\text { fauna }\end{array}$ & $\begin{array}{l}\text { In this paper, the authors collect extensive spatially- } \\
\text { explicit information for four consecutive winters } \\
\text { (2008-2012) on the type, distribution, and abundance of } \\
\text { derelict fishing gear and bycatch in Virginia waters of } \\
\text { Chesapeake Bay. }\end{array}$ \\
\hline
\end{tabular}

Regarding the impact of marine plastic littering on tourism, one should first address its economic significance. Marine tourism has turned out to be an area with special potential to support sustainable growth and emerged as an essential component of the global tourism industry (Hall \& Page, 2014). It is inextricably linked to the "blue" economy, which, according to the World Bank, promotes the "sustainable use of ocean resources for economic growth, improved livelihoods, and jobs while preserving the health of the ocean ecosystem" (DirectorateGeneral for Maritime Affairs and Fisheries, 2019). Maritime (water-based), coastal (beach-based) and cruise tourism are the main manifestations of marine tourism, forming crucial sources of growth and employment thanks to a large and diversified workforce involved in hotels, restaurants, stores and transportation. As a result of these employment opportunities, the living standards of the local population improve, leading to an increase in consumption expenditure and, consequently, an economic boom (Bunghez, 2016). The marine tourism industry employs roughly 5.4 million people worldwide and creates a gross value of almost $\$ 543.5$ billion a year, whereas, in Europe, it results in 3.2 million jobs, with an annual value of \$201 billion (European Commission, 2012).

Still, marine ecosystem degradation due to plastic pollution could undermine marine tourism and lead to economic decline (WHO, 1990). In particular, the presence of marine plastic debris leads to poor aesthetics of recreational water areas (Fanshawe \& Everard, 2002). Deterioration of a tourist destination due to marine pollutants may deter visitors (Godlee $\&$ Walker, 1991). The decrease in the number of coastal visitors, hence, leads to losses of revenue, which in turn has a negative impact on the regional economy. These effects can either be short-term or long-term. The former occur in cases where marine litter is washed up as a result of natural disasters, such as inundations 
or tidal waves, while the latter result from debris accumulation, tarnishing the reputation of an area, thereby discouraging private investment in tourism development (McIIgorm et al., 2011).

Additionally, apart from being a blot on the landscape, plastic pollution adversely affects recreational activities, such as diving, by hindering propeller efficiency, as well as swimming (Philipp, 1992). For instance, in 1987 and 1988, beach closures in New York and New Jersey, USA, because of debris, in combination with tourists' lack of confidence in water conditions, resulted in revenue losses amounting to several billions of dollars (Valle-Levinson \& Swanson, 1991). The economic aspects and quantitative estimates associated with the cost of marine pollution to the tourism industry have been extensively reviewed by Rees and Bartram (Rees \& Bartram, 2002). It concludes that the aforementioned repercussions can be detrimental to the economy, which is heavily contingent upon the marine tourism sector. For example, on the island of Geoje in South Korea, the presence of marine litter after a massive rainstorm in 2011 is assessed to have resulted in revenue losses of between $\$ 29$ and $\$ 37$ million, as a result of a decrease of 560,228 visitors (Jang et al., 2014). In Sweden, reduced tourism because of waste on the Skagerrak coast of Bohuslän, is evaluated to result in approximately annual losses of $\$ 25.3$ million and 150 man-years of work (Fanshawe \& Everard, 2002).

Table 2: Economic Impacts on the Tourism Industry

\begin{tabular}{lll}
\hline \multicolumn{1}{c}{ Author, Year } & \multicolumn{1}{c}{ Title } & \multicolumn{1}{c}{ Description } \\
\hline Hall \& Page, 2014 & $\begin{array}{l}\text { The Geography of Tourism } \\
\text { and Recreation: Space, } \\
\text { Place and Environment }\end{array}$ & $\begin{array}{l}\text { This paper provides a comprehensive introduction } \\
\text { to tourism, leisure and recreation and explains their } \\
\text { interrelationships. }\end{array}$ \\
\hline $\begin{array}{l}\text { Directorate- } \\
\text { General for } \\
\text { Maritime Affairs } \\
\text { and Fisheries, }\end{array}$ & $\begin{array}{l}\text { The EU blue economy } \\
\text { report 2019 }\end{array}$ & $\begin{array}{l}\text { This report analyses the scope and size of the Blue } \\
\text { Economy in the European Union, solidifying a baseline } \\
\text { to support policymakers and stakeholders in the quest } \\
\text { for a sustainable development of oceans, sea and coastal } \\
\text { resources. }\end{array}$ \\
\hline Bunghez, 2016 & $\begin{array}{l}\text { The importance of } \\
\text { Tourism to a Destination's } \\
\text { Economy }\end{array}$ & $\begin{array}{l}\text { This paper aims at analyzing the connections and } \\
\text { implications of tourism in the economic field, as well as } \\
\text { the factors that determine the degree to which tourism } \\
\text { contributes to the economy of a destination. }\end{array}$ \\
\hline $\begin{array}{l}\text { European } \\
\text { Commission, }\end{array}$ & $\begin{array}{l}\text { Blue Growth Study - } \\
\text { Scenarios and drivers for } \\
\text { Sustainable Growth from } \\
\text { the Oceans, Seas and } \\
\text { Coasts }\end{array}$ & $\begin{array}{l}\text { This report builds on earlier policy initiatives to } \\
\text { recognize the potential of marine resources and aids } \\
\text { in realizing the Europe 2020 strategy towards smart, } \\
\text { sustainable and inclusive growth. }\end{array}$ \\
\hline $\begin{array}{l}\text { Fanshawe \& } \\
\text { Everard, 2002 }\end{array}$ & $\begin{array}{l}\text { The impacts of marine } \\
\text { litter. }\end{array}$ & $\begin{array}{l}\text { This paper offers an early review of existing approaches, } \\
\text { but is unique in the emphasis placed on trying to } \\
\text { evaluate the economic impact of marine litter, including } \\
\text { the hidden costs. }\end{array}$ \\
\hline $\begin{array}{l}\text { Godlee \& Walker, } \\
1991\end{array}$ & $\begin{array}{l}\text { Importance of a healthy } \\
\text { environment }\end{array}$ & $\begin{array}{l}\text { This paper discusses the importance of a healthy } \\
\text { environment, by exploring the destructive environmental } \\
\text { consequences of anthropogenic activities and their } \\
\text { subsequent adverse effects on human health. }\end{array}$ \\
\hline & &
\end{tabular}




\begin{tabular}{lll}
\hline $\begin{array}{l}\text { McIlgorm et al. } \\
2011\end{array}$ & $\begin{array}{l}\text { The economic cost and } \\
\text { control of marine debris } \\
\text { damage in the Asia-Pacific } \\
\text { region }\end{array}$ & $\begin{array}{l}\text { This paper examines the economic costs associated with } \\
\text { marine debris and suggests a simple marine debris cycle } \\
\text { model discussing the costs and benefits of prevention, } \\
\text { clean-up and utilization of biodegradable materials is } \\
\text { presented. }\end{array}$ \\
\hline Philipp, 1992 & $\begin{array}{l}\text { Environmental quality } \\
\text { objectives and their } \\
\text { relationship to health } \\
\text { indicators }\end{array}$ & $\begin{array}{l}\text { This paper assesses a broad spectrum of environmental } \\
\text { quality objectives and their relationship to various health } \\
\text { indicators. }\end{array}$ \\
\hline Valle-Levinson \& & $\begin{array}{l}\text { Wind-induced scattering } \\
\text { of medically-related and } \\
\text { sewage-related floatables }\end{array}$ & $\begin{array}{l}\text { This paper discusses the wind-induced scattering of } \\
\text { medically- as well as sewage-related floatables. }\end{array}$ \\
\hline $\begin{array}{l}\text { Rees \& Bartram, } 1991 \\
2002\end{array}$ & $\begin{array}{l}\text { Monitoring bathing waters: } \\
\text { a practical guide to the } \\
\text { design and implementation } \\
\text { of assessments and } \\
\text { monitoring programmes }\end{array}$ & $\begin{array}{l}\text { This book provides comprehensive guidance for the } \\
\text { design, planning and implementation of assessments } \\
\text { and monitoring programmes for water bodies used for } \\
\text { recreation. }\end{array}$ \\
\hline Jang et al. 2014 & $\begin{array}{l}\text { Estimation of lost tourism } \\
\text { revenue in Geoje Island } \\
\text { from the 2011 marine } \\
\text { debris pollution event in } \\
\text { South Korea }\end{array}$ & $\begin{array}{l}\text { This study estimates the lost tourism revenue in Geoje } \\
\text { Island from the 2011 marine debris pollution event in } \\
\text { South Korea. }\end{array}$ \\
\hline
\end{tabular}

Merchant shipping is another area where the impact of plastic marine pollution is quite significant. The international shipping industry is accountable for transporting around $90 \%$ of world commerce (International Maritime Organization, N.D.). With more than 50,000 merchant ships trading intercontinentally, involving more than 150 nations, the number of mariners registered worldwide has been reported to exceed a million. Bearing in mind that yearly revenue from the freight rates of merchant vessels is estimated to be over $\$ 500$ billion, it is indisputable that merchant shipping is one the most dynamic and thriving sectors of the global economy. The presence of marine litter significantly impedes commercial shipping and increases its cost both directly and indirectly. The direct costs are associated with marine litter collisions and subsequent accidental loss of cargo, while the indirect ones are related to repairs, shutdowns and public image. Port cleaning costs can also indirectly burden the shipping sector. I The total costs of the abovementioned consequences of marine littering is estimated at \$279 million per year
(UNEP, 2016b).

More specifically, clashes with marine litter could damage vessels, pose a navigational hazard for shipping or even a threat to human safety. Lost containers pose a major risk due to their size and ability to float for weeks. Smaller marine litter may also endanger ships, being responsible for costs associated with propeller repair or engine shutdown. At the same time, elevated levels of congestion in ports increase the risk of collision with waste. Therefore, debris is systematically removed by port authorities in order to ensure the infrastructure's safety and reliability (Mouat et al., 2010). Removal of waste from Esbjerg port in Denmark costs $\$ 86,695$, annually (Hall, 2000). Additionally, excessive expenditure is ultimately caused by loss of cargo, since the average value per ship is $\$ 20,000-\$ 24,500$. This cost is likely to be exceeded in case insurance payments are required (UNEP, 2016c).

Last, but not least, the quality of the marine environment is directly related with and contributes to human health and wellbeing, thus its deterioration has significant health impacts and social repercussions. In particular, 
its imperilment is capable of jeopardizing a society's food security and health, elevating risk of injury or death, and cause loss of intrinsic natural value (Naeem et al., 2016). It is beyond a shadow of a doubt that marine plastic debris is compromising food security through exposing humans to microplastics and their contaminants (De-La Torre, 2019). Nevertheless, even though it is proven that marine plastic debris endangers the equilibrium of marine ecosystems, its repercussions on human health have not yet been thoroughly quantified (Barboza \& Gimenez, 2015; Vethaak \& Leslie 2016; Moy et al., 2018).

The pathway through which microplastics imperil food safety and health is the consumption of marine fauna. A wide variety of commercially consumable marine organisms, including fish, such as cod, mackerel, pilchard, red mullet, sea bass, swordfish, grouper, as well as, shellfish, such as bivalves (clams, scallops, mussels, oysters) and crustaceans (shrimp, lobsters, crabs) have been detected with microplastics in their digestive tract or intestines (Lusher et al., 2013; Bråte et al., 2016; Sun et al., 2017). In particular, 11 out 25 species, which are important to global sea fishing, were reported to be contaminated with microplastics (Food and Agriculture Organization of the United Nations, 2017).

Shellfish consumption emerges as the most perilous since their filter feeding mechanism leads to the accumulation of microplastics. Furthermore, a factor enhancing the aforementioned risk is that shellfish are being consumed whole, without having their intestines removed. Van Cauwenberghe and Janssen considered that in Europe, each consumer's uptake of microplastics from their consumption of shellfish adds up to 11,000 particles (size range $5-1000 \mu \mathrm{m}$ ) on a yearly basis, while in countries with low shellfish consumption, 1,800 microplastic particles are ingested on average per person annually (Van Cauwenberghe \& Janssen, 2014). As far as shrimp consumption is concerned, calculations demonstrate an average of 175 microplastic particles (size range 200-1000 $\mu \mathrm{m}$ ) per capita per year (Devriese et al., 2015). Microplastics have also been detected in mussels in France, Italy, Denmark, Spain and the Netherlands (Vandermeersch et al., 2015b). As to edible fish, if consumed disemboweled, the danger is

Table 3: Economic Impacts of the Shipping Industry

\begin{tabular}{lll}
\hline \multicolumn{1}{c}{ Author, Year } & \multicolumn{1}{c}{ Title } & \multicolumn{1}{c}{ Description } \\
\hline International & IMO Profile-Overview & $\begin{array}{l}\text { This report provides information about the safety and } \\
\text { Maritime }\end{array}$ \\
Security of shipping and the prevention of marine and \\
atmospheric pollution by ships.
\end{tabular}

UNEP, 2016b Marine litter - a $\quad$ This report presents a model and the simulation of the modelling study distribution of floating plastics based on the estimated influx of plastic due to inadequate waste treatment.

\begin{tabular}{lll}
\hline Mouat et al. 2010; & $\begin{array}{l}\text { Economic Impacts of } \\
\text { marine litter }\end{array}$ & $\begin{array}{l}\text { This study addresses the economic impacts of marine } \\
\text { litter. }\end{array}$ \\
\hline Hall, 2000 & $\begin{array}{l}\text { Tourism Planning: } \\
\text { Policies, Processes and } \\
\text { Relationships }\end{array}$ & $\begin{array}{l}\text { This paper presents a wide range of international case } \\
\text { studies and examples highlighting sustainability as a } \\
\text { current core tourism concern. }\end{array}$ \\
\hline UNEP, 2016c & $\begin{array}{l}\text { Marine litter: socio- } \\
\text { economic study }\end{array}$ & $\begin{array}{l}\text { This study analyzes the socioeconomic impact of marine } \\
\text { plastic litter, focusing on the cost of actions undertaken } \\
\text { to address the problem as well as the potential cost of } \\
\text { inaction. }\end{array}$ \\
\hline
\end{tabular}


minimized as the exposure to microplastics in their gastrointestinal tract is avoided (Compa et al., 2018).

Regarding the health impact of the consumption of microplastics by humans, it has been proven that microplastics are carriers of infectious agents, including harmful bacteria ( $\mathrm{Lu}$ et al., 2019). Nonetheless, the greatest menace accompanying the consumption of microplastics lies in particle toxicity (Rist et al. 2018). Chemical substances in or absorbed by plastics, including persistent organic pollutants (POPs), like polychlorinated biphenyls (PCBs) and organochlorine pesticides, such as dichlorodiphynyltrichloroethane (DDT), are transferred to filter-feeding organisms and other invertebrates where they bioaccumulate (Wright et al., 2013; Fossi et al., 2014). Their concentration then increases at each successive trophic level leading to biomagnification. Therefore, humans are affected the most being at the top of the food chain (Kelly et al., 2007). The forenamed chemicals have been linked to medical conditions due to their toxicological consequences, including immune system suppression, hormone level alterations, abnormal inflammatory responses, malignant tumors, developmental disabilities and reproductive abnormalities (Carney Almroth et al., 2019). However, a meticulous health risk assessment is not achievable, since the processes associated with the assimilation of microplastics in human cells and their alleged impact have not yet been established and should be rigorously explored in the years to come.

More imminent dangers can also be attributed to marine plastic pollution. For example, floating plastic waste poses a grave

Table 4: Impacts on human food security

\begin{tabular}{|c|c|c|}
\hline Author, Year & Title & Description \\
\hline Naeem et al. 2016 & $\begin{array}{l}\text { Biodiversity and human well- } \\
\text { being: an essential link for } \\
\text { sustainable development }\end{array}$ & $\begin{array}{l}\text { This paper explores how published conceptual } \\
\text { frameworks consider the extent to which the } \\
\text { biodiversity/human well-being links are being } \\
\text { integrated into public discourse and scientific } \\
\text { research. }\end{array}$ \\
\hline $\begin{array}{l}\text { Barboza \& } \\
\text { Gimenez, } 2015\end{array}$ & $\begin{array}{l}\text { Microplastics in the marine } \\
\text { environment: current trends } \\
\text { and future perspectives }\end{array}$ & $\begin{array}{l}\text { This paper uses a scientometric approach to } \\
\text { systematically assess and quantify advances in } \\
\text { knowledge related to microplastics in the marine } \\
\text { environment. }\end{array}$ \\
\hline $\begin{array}{l}\text { Vethaak \& Leslie } \\
2016\end{array}$ & $\begin{array}{l}\text { Plastic debris is a human } \\
\text { health issue }\end{array}$ & $\begin{array}{l}\text { This paper discusses how plastic debris is able } \\
\text { to compromise human health through acting as a } \\
\text { pathogen and parasite vector as well as through } \\
\text { particle and chemical toxicity. }\end{array}$ \\
\hline Moy et al. 2018 & $\begin{array}{l}\text { Mapping coastal marine debris } \\
\text { using aerial imagery and } \\
\text { spatial analysis }\end{array}$ & $\begin{array}{l}\text { This study is the first to systematically quantify, } \\
\text { categorize, and map marine macro-debris across the } \\
\text { main Hawaiian Islands, including remote areas. }\end{array}$ \\
\hline Lusher et al. 2013 & $\begin{array}{l}\text { Occurrence of microplastics } \\
\text { in the gastrointestinal tract of } \\
\text { pelagic and demersal fish from } \\
\text { the English Channel }\end{array}$ & $\begin{array}{l}\text { This study documents microplastics in } 10 \text { species of } \\
\text { fish from the English Channel. }\end{array}$ \\
\hline Bråte et al. 2016 & $\begin{array}{l}\text { Plastic ingestion by Atlantic } \\
\text { cod (Gadus morhua) from the } \\
\text { Norwegian coast }\end{array}$ & $\begin{array}{l}\text { This study documents the occurrence of microplastic, } \\
\text { mesoplastic and macroplastic in Atlantic cod. }\end{array}$ \\
\hline Sun et al. 2017 & $\begin{array}{l}\text { Ingestion of microplastics by } \\
\text { natural zooplankton groups in } \\
\text { the northern South China Sea }\end{array}$ & $\begin{array}{l}\text { This paper studies the ingestion of microplastics by } \\
\text { five natural zooplankton groups in the northern South } \\
\text { China Sea. }\end{array}$ \\
\hline
\end{tabular}




\begin{tabular}{|c|c|c|}
\hline $\begin{array}{l}\text { Food and } \\
\text { Agriculture } \\
\text { Organization } \\
\text { of the United } \\
\text { Nations, } 2017\end{array}$ & $\begin{array}{l}\text { Microplastics in fisheries } \\
\text { and aquaculture - Status of } \\
\text { knowledge on their occurrence } \\
\text { and implications for aquatic } \\
\text { organisms and food safety }\end{array}$ & $\begin{array}{l}\text { This report explores the occurrence and impact } \\
\text { of microplastics on marine organisms, including } \\
\text { species of commercial importance for fisheries and } \\
\text { aquaculture. Moreover, the risks in terms of food } \\
\text { safety are discussed. }\end{array}$ \\
\hline $\begin{array}{l}\text { Van } \\
\text { Cauwenberghe \& } \\
\text { Janssen, } 2014\end{array}$ & $\begin{array}{l}\text { Microplastics in bivalves } \\
\text { cultured for human } \\
\text { consumption }\end{array}$ & $\begin{array}{l}\text { This paper investigates the presence of microplastics } \\
\text { in two species of commercially grown bivalves. }\end{array}$ \\
\hline $\begin{array}{l}\text { Vandermeersch et } \\
\text { al. } 2015 \mathrm{~b}\end{array}$ & $\begin{array}{l}\text { A critical view on microplastic } \\
\text { quantification in aquatic } \\
\text { organisms }\end{array}$ & $\begin{array}{l}\text { This paper conducts a literature review on all } \\
\text { available methods, with respect to the quantification } \\
\text { of microplastics in biota. }\end{array}$ \\
\hline Compa et al. 2018 & $\begin{array}{l}\text { Ingestion of microplastics } \\
\text { and natural fibres in Sardina } \\
\text { pilchardus (Walbaum, 1792) } \\
\text { and Engraulis encrasicolus } \\
\text { (Linnaeus, 1758) along the } \\
\text { Spanish Mediterranean coast. }\end{array}$ & $\begin{array}{l}\text { This paper assesses the ingestion of microplastics and } \\
\text { natural fibers for two commercial fish species in the } \\
\text { western Mediterranean Sea. }\end{array}$ \\
\hline Lu et al. 2019 & $\begin{array}{l}\text { Interaction between microplastics } \\
\text { and microorganism as well as gut } \\
\text { microbiota: A consideration on } \\
\text { environmental animal and human } \\
\text { health }\end{array}$ & $\begin{array}{l}\text { In this review, the authors summarized the } \\
\text { interactions between microplastics and } \\
\text { microorganisms as well as gut microbiota, and } \\
\text { considered the possible impacts of microplastics on } \\
\text { environmental animal and human health. }\end{array}$ \\
\hline Rist et al. 2018 & $\begin{array}{l}\text { A critical perspective on early } \\
\text { communications concerning } \\
\text { human health aspects of } \\
\text { microplastics. }\end{array}$ & $\begin{array}{l}\text { This paper takes into consideration the unbalanced } \\
\text { current debate on human health effects of plastics } \\
\text { and the disproportionate focus on microplastics in } \\
\text { individual food products. The authors urge for a more } \\
\text { balanced discussion on human exposure to plastics. }\end{array}$ \\
\hline Wright et al. 2013 & $\begin{array}{l}\text { The physical impacts of } \\
\text { microplastics on marine } \\
\text { organisms: a review. } \\
\text { Environmental pollution }\end{array}$ & $\begin{array}{l}\text { This review focuses on marine invertebrates and their } \\
\text { susceptibility to the physical impacts of microplastic } \\
\text { uptake. }\end{array}$ \\
\hline Fossi et al. 2014 & $\begin{array}{l}\text { Large filter feeding marine } \\
\text { organisms as indicators of } \\
\text { microplastic in the pelagic } \\
\text { environment: the case studies } \\
\text { of the Mediterranean basking } \\
\text { shark (Cetorhinus maximus) } \\
\text { and fin whale (Balaenoptera } \\
\text { physalus). }\end{array}$ & $\begin{array}{l}\text { This paper presents the case studies of the } \\
\text { Mediterranean fin whale (Balaenoptera physalus) and } \\
\text { basking shark (Cetorhinus maximus), explores the } \\
\text { toxicological effects of microplastics and measures } \\
\text { the levels of phthalates in both species. }\end{array}$ \\
\hline Kelly et al. 2007 & $\begin{array}{l}\text { Food web-specific } \\
\text { biomagnification of persistent } \\
\text { organic pollutants }\end{array}$ & $\begin{array}{l}\text { This paper studies the food web-specific } \\
\text { biomagnification of persistent organic pollutants. }\end{array}$ \\
\hline $\begin{array}{l}\text { Carney Almroth et } \\
\text { al. } 2019\end{array}$ & $\begin{array}{l}\text { Marine plastic pollution: } \\
\text { sources, impacts, and policy } \\
\text { issues. }\end{array}$ & $\begin{array}{l}\text { This paper provides a brief introduction to plastic } \\
\text { materials, marine plastic pollution, and its potential } \\
\text { effects on marine ecosystems and human health. Some } \\
\text { of the policy and technical issues are discussed and } \\
\text { priorities for further research are suggested. }\end{array}$ \\
\hline
\end{tabular}


threat of injury or death by blocking ship propellers, leading to collision with floating or semi-submerged large objects, such as plastic insulated containers (Frey \& DeVogelaere, 2014). In 2005, the US Coast Guard reported 269 maritime accidents, resulting in 15 deaths and 116 injuries, attributed to submerged debris (Letcher \& Vallero, 2019). In South Korea, 9\% of all maritime accidents, from 1996 to 1998, took place on account of floating marine objects. In the worst case scenario, a ship overturned when a derelict fishing rope got tangled in its propellers, leading to 292 casualties (UNEP, 2016b). According to the OverReview of Marine Casualties and Incidents 2015, from 2011 to 2014, ships striking or being struck by external objects (e.g. lost cargo), were the second most frequent cause of marine casualties.

Injury or death may also occur due to entanglement during recreational activities, such as swimming or diving. Marine debris poses a great threat to divers harvesting marine organisms from the seabed, due to colonial marine flora which can restrict visibility and subsequently lead to entanglement. Once entangled by marine litter, such as derelict fishing gear, divers are often faced with difficulties in escaping and seeking help (Kershaw, 2016). Entrapment and entanglement are responsible for approximately $20 \%$ of mortal diving accidents (Vann \& Lang, 2010). An even higher risk is present when rescuing trapped live animals (e.g. sea birds, turtles or cetaceans), which justifies the necessity of professional intervention.

Finally, loss of intrinsic value refers to changes in perceived environmental value on account of pollution, as manifested by significant aesthetic blight and images of wounded or deceased emblematic species. In general,

Table 5: Threat of injury or death

\begin{tabular}{ll}
\hline \multicolumn{1}{c}{ Author, Year } & \multicolumn{1}{c}{ Title } \\
\hline Frey \& & A review of resource \\
DeVogelaere, & Management Strategies for \\
2014 & Protection of Seamounts.
\end{tabular}

\begin{tabular}{|c|c|c|}
\hline $\begin{array}{l}\text { Letcher \& Vallero, } \\
2019\end{array}$ & $\begin{array}{l}\text { Waste: A handbook for } \\
\text { management }\end{array}$ & $\begin{array}{l}\text { This handbook gives a broad coverage of waste in our } \\
\text { society, examining a wide range of waste streams. }\end{array}$ \\
\hline
\end{tabular}

This paper conducts a review of resource management strategies for the protection of seamounts.

$\begin{array}{ll}\text { UNEP, 2016b } & \begin{array}{l}\text { Marine litter - a modelling } \\ \text { study }\end{array}\end{array}$

This modelling study simulates the distribution of floating plastic based on the estimated influx of plastic due to inadequate waste treatment.

\begin{tabular}{lll}
\hline Marine Review of & ANNUAL OVERVIEW & This report consists of a high-level analysis of accidents \\
Marine Casualties, & OF MARINE & reported by the EU Member States in European Marine \\
2015 & CASUALTIES AND & Casualty Information Platform (EMCIP). \\
& INCIDENTS 2015 &
\end{tabular}

\begin{tabular}{lll}
\hline Kershaw, 2016 & $\begin{array}{l}\text { Marine plastic debris and } \\
\text { microplastics-Global } \\
\text { lessons and research to } \\
\text { inspire action and guide } \\
\text { policy change }\end{array}$ & $\begin{array}{l}\text { This report presents both short- and long-term } \\
\text { approaches to the problem of marine plastic debris } \\
\text { and microplastics. It provides an overview of the latest } \\
\text { science and experiences, identifies priority areas of } \\
\text { action and points out areas requiring more research. }\end{array}$ \\
\hline $\begin{array}{l}\text { Vann \& Lang, } \\
2010\end{array}$ & $\begin{array}{l}\text { Recreational Diving } \\
\text { Fatalities- Workshop } \\
\text { Proceedings. }\end{array}$ & $\begin{array}{l}\text { The works described in these proceedings study the risks } \\
\text { of dying during recreational diving and assesses ways of } \\
\text { reducing their numbers. }\end{array}$
\end{tabular}


it is hard to reliably assess this effect, apart from cases where observable and quantifiable behavioral changes are detected, as in the above mentioned examples. It can reasonably be assumed that the closer the relationship to an aesthetically displeasing marine area, the greater the sense of loss is. Moreover, the deprivation of benefits associated with marine environments, such as enhanced physical health, reduced stress and ameliorated concentration might exacerbate the bearish sentiment (GESAMP, 2016).
As far as the aforementioned iconic fauna is concerned (e.g. green turtle, polar bear, emperor penguin etc.), it holds a cultural and emotional significance. Its existence value can be justified by extensive evidence indicating that humans feel comforted by the knowledge that it is safe and will remain so for succeeding generations (Aanesen et al., 2015). Nevertheless, entanglement, ingestion and contamination from chemicals in or absorbed by plastic are current actual threats, being capable of entailing deleterious effects on their growth,

Table 6: Intrinsic value loss

\begin{tabular}{|c|c|c|}
\hline Author, Year & Title & Description \\
\hline GESAMP, 2016 & $\begin{array}{l}\text { Sources, fate and effects of } \\
\text { microplastics in the marine } \\
\text { environment: Second } \\
\text { phase assessment part one }\end{array}$ & $\begin{array}{l}\text { This report provides an update and further assessment } \\
\text { of the sources, fate and effects of microplastics in the } \\
\text { marine environment. }\end{array}$ \\
\hline $\begin{array}{l}\text { Aanesen } \text { et al. } \\
2015\end{array}$ & $\begin{array}{l}\text { Willingness to pay for } \\
\text { unfamiliar public goods: } \\
\text { preserving cold-water coral } \\
\text { in Norway }\end{array}$ & $\begin{array}{l}\text { This paper presents a discrete choice experiment, } \\
\text { designed and implemented in a valuation workshop } \\
\text { setting in order to derive estimates of participants' } \\
\text { willingness to pay for increasing the protection of cold- } \\
\text { water coral. }\end{array}$ \\
\hline Allen et al. 2012 & $\begin{array}{l}\text { Entanglement of grey seals } \\
\text { Halichoerus grypus at a } \\
\text { haul out site in Cornwall, } \\
\text { UK. }\end{array}$ & $\begin{array}{l}\text { This paper investigates the entanglement of grey seals } \\
\text { Halichoerus grypus at a site in the southwest UK. }\end{array}$ \\
\hline $\begin{array}{l}\text { Butterworth \& } \\
\text { Clegg, } 2012\end{array}$ & $\begin{array}{l}\text { Untangled, Marine debris: } \\
\text { a global picture of the } \\
\text { impact on animal welfare } \\
\text { and of animal-focused } \\
\text { solutions }\end{array}$ & $\begin{array}{l}\text { This report presents a review of a large body of } \\
\text { published literature on marine debris, its impacts on the } \\
\text { welfare of animals, and mitigation efforts already in } \\
\text { place. }\end{array}$ \\
\hline Börger et al. 2014; & $\begin{array}{l}\text { Valuing conservation } \\
\text { benefits of an offshore } \\
\text { marine protected area }\end{array}$ & $\begin{array}{l}\text { This study scrutinizes the applicability of a discrete } \\
\text { choice experiment to value the expected benefits arising } \\
\text { from the conservation of an offshore sandbank in UK } \\
\text { waters. }\end{array}$ \\
\hline $\begin{array}{l}\text { Jobstvogt et al. } \\
2014\end{array}$ & $\begin{array}{l}\text { Looking below the surface: } \\
\text { The cultural ecosystem } \\
\text { service values of UK } \\
\text { marine protected areas } \\
\text { (MPAs). }\end{array}$ & $\begin{array}{l}\text { This paper presents a case study from the UK National } \\
\text { Ecosystem Assessment follow-on phase that elicited } \\
\text { divers' and anglers' willingness to pay for potential } \\
\text { marine protected areas. }\end{array}$ \\
\hline UNEP, 2015a & $\begin{array}{l}\text { Biodegradable Plastics } \\
\text { and Marine Litter. } \\
\text { Misconceptions, concerns } \\
\text { and impacts on marine } \\
\text { environments. United } \\
\text { Nations Environment } \\
\text { Programme (UNEP) }\end{array}$ & $\begin{array}{l}\text { This paper provides a summary of some of the key } \\
\text { issues surrounding the biodegradability of plastics } \\
\text { in the oceans. It explores whether the adoption of } \\
\text { biodegradable plastics will reduce the impact of marine } \\
\text { plastics overall. The paper also addresses the lack of } \\
\text { public knowledge about biodegradable plastics. }\end{array}$ \\
\hline
\end{tabular}




\begin{tabular}{lll}
\hline UNEP, 2015b & $\begin{array}{l}\text { Global waste management } \\
\text { outlook }\end{array}$ & $\begin{array}{l}\text { This report establishes the rationale and tools for } \\
\text { taking a holistic approach towards waste management } \\
\text { and recognizing waste and resource management as a } \\
\text { significant contributor to sustainable development and } \\
\text { climate change mitigation. }\end{array}$ \\
\hline UNEP, 2014b & $\begin{array}{l}\text { Valuing Plastics: The } \\
\text { Business Case for } \\
\text { Measuring, Managing and } \\
\text { Disclosing Plastic Use } \\
\text { in the Consumer Goods } \\
\text { Industry }\end{array}$ & $\begin{array}{l}\text { The objective of this report is to help companies manage } \\
\text { the opportunities and risks associated with plastic use. } \\
\text { In order to provide a sense of scale, the report sets out } \\
\text { to quantify the physical impacts of plastic use translated } \\
\text { into monetary terms. This metric can be used to help } \\
\text { understand the magnitude of the opportunities, and the } \\
\text { tangible benefits to stakeholders. }\end{array}$ \\
& Goal 14: Life below water & $\begin{array}{l}\text { This report presents the sustainable development goals } \\
\text { proposed by UNDP and aims to sustainably manage and } \\
\text { protect marine and coastal ecosystems from pollution, as } \\
\text { well as addressing the impacts of ocean acidification. }\end{array}$ \\
\hline UNDP, 2015 & &
\end{tabular}

swimming performance, respiration, circulation and reproduction as well as mortality (Allen et al., 2012, Butterworth \& Clegg, 2012). The considerable public concern about the above mentioned ramifications of plastic suggests that even single incidents might entail undesirable effects on prosperity and that the relationship between ecosystem imbalances and human wellbeing loss is not essentially linear (Börger et al., 2014; Jobstvogt et al., 2014).

Numerous efforts have been made to develop non-use value quantification methodologies (UNEP, 2015a; UNEP, 2015b), but these analyses are often impeded due to shortage of relevant and reliable data. In spite of these shortcomings, a plethora of possible evaluations is likely to be carried out, based on a relatively limited number of studies, such as calculating the cost of protection and preservation of environmental goods, whether aimed at future exploitation or not. These analyses can be applied globally, in different social and economic environments, regardless of indigenous cultural values, in order to illustrate the possible extent of such costs (UNEP, 2014b). A clean, healthy and safe ocean is considered to have intrinsic value, whose preservation remains the primary focus of the Sustainable Development Goals (SDGs) along with a plethora of other initiatives calling for the protection of marine and coastal ecosystems from pollution (UNDP, 2015). At the same time, it also includes other forms of non-use values, which are defined as: i) option value willingness to protect the environment for future use, ii) existence value - willingness to preserve the environment, irrespective of potential future use and iii) bequest value - willingness to ensure the availability of a well-functioning hydrosphere for subsequent generations to inherit (UNEP, 2014b).

In the next section, examples of preventive measures and coping strategies aimed at marine sustainability are discussed.

\section{Prevention Efforts and Coping Mechanisms for Marine Sustainability}

The presence of plastic waste in marine environments, in combination with the ongoing prevention efforts and coping strategies, are not recent challenges. The nature of the solutions applied over the last 50 years is multifaceted. However, as far as prevention is concerned, the response from responsible international legal instruments, both on land and sea, is limited. The existing international agreements mostly address marine-related sources of plastic, which are deemed responsible for a minority of marine plastic pollution compared to land-based sources, which is of major concern (Naidoo, 2015). Three examples of such agreements are 
described in chronological order, as follows.

First and foremost, the Convention on the Prevention of Marine Pollution by Dumping of Wastes and Other Matter (London Convention) is deemed to be one of the more successful pollution-related agreements of the 1970s. This Convention was designed to establish the fundamental framework for worldwide regulation of the intentional disposal of all wastes into the ocean, and has been in force since 1975. Secondly, the International Convention for the Prevention of Pollution from Ships (MARPOL 73/78) was signed in 1973. Its objective was to prevent and control intentional operational discharges from ships, even though a complete prohibition on waste disposal at sea was not enacted until 1988. Although 134 countries agreed to eliminate ocean plastics disposal, research has demonstrated that the issue of marine debris has deteriorated since MARPOL $73 / 78$ was signed, highlighting the importance of addressing land-based sources of plastic debris as well. Last but not least, the Honolulu Strategy outlines the prevention and management of marine debris, aspiring to reduce the amount and impact of marine-based and land-based sources of marine debris, as well as debris accumulation (UNEP, 2015a; UNEP, 2015b).

Plastic waste mismanagement is sentencing the marine environment to inevitable degradation and immediate action, in the form of prevention and proper management, needs to be taken. However, as far as international law agreements go, even though the role of insufficient waste management systems is recognized, these mechanisms have been proven to be ineffective in manifold ways. In particular, they contain no minimum standard that nations are required to abide by. Within this context, such frameworks are too general to expect international conformity. At the same time, they are not enforceable since it is not possible to identify the source of plastics, once they infiltrate the ocean. Finally, the management of landbased plastic sources is intrinsically a matter to be locally addressed, hence, international agreements run the risk of encroaching on the competence of relevant national authorities.

As to coping mechanisms applied, acknowledging the gravity of the situation has led to a growing worldwide commitment to combat marine plastic pollution enabling the emergence of cleanup activities at a global scale. For instance, the Ocean Cleanup (OC) has been considered to be the largest marine cleaning operation in history, with a team of more than 90 engineers, researchers, scientists and computational modelers working daily at its Rotterdam headquarters to rid the world's oceans of plastic. The $\mathrm{OC}$ foundation aims to reduce by half the amount of plastic found in the Great Pacific Garbage Patch in the north central Pacific Ocean in five years. OC's cleaning systems are based on natural agents, such as winds, waves, tides and currents, driving the debris into a collection site. The OC does not stop its efforts in the oceans, but also focuses on one step upstream of the plastic waste chain, by implementing the 'Interceptor', the first scalable solution to prevent plastic waste from entering the oceans from rivers. It is $100 \%$ solarpowered, extracts up to $50,000 \mathrm{~kg}$ of plastic per day autonomously and is able to operate in the majority of the world's most polluting rivers (The Ocean Cleanup, 2019).

The Trash hero is a network which started in Southeast Asia in 2013, with weekly cleanups in Thailand, extending to Indonesia, Myanmar, Malaysia and Singapore, so as to combat the accumulation of plastic and other materials in the ASEAN region. It includes weekly cleanup activities, during which, in 2017, more than 38,000 participants collected a total of 188 tons of waste. Its objective is to recycle as much waste as possible. As for the non-recyclable and non-biodegradable waste, it is used to create "eco-bricks", which are building blocks for construction (Trash Hero, 2018). In a similar vein, the Ocean Conservancy launched the International Coastal Cleanup (ICC), which operates throughout the ASEAN region through coastal cleanup initiatives. Initially, this project exclusively relied on volunteers (Lyons et 
al., 2019). However, in 2012, the Ocean Conservancy launched the Trash Free Seas Alliance, which united the expertise of a number of private companies, academic, public and civil society partners aspiring towards "a healthy ocean free from trash". In 2018, the Trash Free Seas Alliance announced that its members had collectively eliminated 500,000 tons of virgin plastic from products and packaging annually (Ocean Conservancy, 2018).

Returning to Europe, the Plastic Whale $(\mathrm{PW})$ is another example of sustainable marine activity. PW is the first professional plastic fishing company in the world to fish more than 100,000 polyethylene terephthalate (PET) bottles and tons of other waste from the Amsterdam canals (Broek, 2018). The Marine Remote Sensing Group carried out a project, in Lesvos-Greece, aimed at tracking artificial plastic targets on the surface of the Aegean Sea using drones and satellite imaging technology. Its objective was to evaluate the ability of satellites to detect marine litter on the sea surface (Plastic Litter Project 2018, 2018). Last but not least, Marina Trash Skimmer (MTS) is designed to operate on a full-time weekly basis cleaning debris floating in marinas. It uses an industrialsized pool filter able to capture a multitude of debris, including plastic and microplastics while absorbing oil and other contaminants. It can be strategically placed at different locations and has already been used by various marinas in USA and Mexico (Bleier, 2018)

\section{Conclusion}

Plastic marine pollution is a worldwide environmental issue that is growing exponentially due to the rise of throw-away culture, which is characterized by overconsumption and excessive production of disposable products. Marine debris not only jeopardizes the equilibrium of the ecosystem but also compromises economic development affecting fishing, aquaculture, marine tourism and merchant shipping. At the same time, marine pollution is responsible for societal repercussions, such as the endangerment of food security and health due to presence of microplastics in seafood, threat of injury or death from ship collisions or human entanglement in debris, and loss of intrinsic natural value.

Undoubtedly, the protection and preservation of the oceans are an investment for the future as well as a moral obligation, translating into the need to introduce preventive mechanisms to decrease plastic input along with coping strategies to alleviate the impact of existing waste. It is imperative that society actively block the entry of waste into the ocean, irrespective of possible financial burdens entailed. In order to face this problem, along with its economic and societal consequences, numerous initiatives have been taken, such as international agreements and marine cleaning operations. Ultimately, all sectors of the community need to take their individual steps. Thinking globally and acting locally in combination with the implementation of legislative measures and raising ecological consciousness through education, are undoubtedly the solution to achieve marine sustainability in the future.

In this paper, the existing literature was studied and analysed in order to provide a better understanding on how marine plastic pollution affects the economy and society as well as summarizing previous preventing and mitigating efforts. Furthermore, it shed light on dimensions of the problem requiring to be tackled in succeeding studies, such as the quantification of microplastics in edible tissues of consumable marine animal species combined with the creation of food security risk assessment frameworks.

Nonetheless, in spite of its merits, this literature review is subject to some limitations. First, the selection of the 313 papers included in the study sample was a result of a consensus approach. The consensus was reached after all the authors presented their arguments and though ultimately unanimous, one cannot overlook the fact that there may be an oversight bias to the final selection. Second, as described in the methodology section, a set of inclusion criteria was applied that excluded conference papers and all papers before the year 2000. The 
authors acknowledge the fact that noteworthy publications do exist in these two categories.

\section{Acknowledgements}

The present work is co-funded by the European Union and Greek national funds through the Operational Program "Competitiveness, Entrepreneurship and Innovation" (EPAnEK), under the call "RESEARCH-CREATEINNOVATE" (project code: T1EAK-05095 and Acronym: TRACKPLAST)

\section{References}

Aanesen, M., Armstrong, C., Czajkowski, M., Falk-Petersen, J., Hanley, N., \& Navrud, S. (2015). Willingness to pay for unfamiliar public goods: Preserving cold-water coral in Norway. Ecological Economics, 112, 5367.

Alimi, O. S., Farner Budarz, J., Hernandez, L. M., \& Tufenkji, N. (2018). Microplastics and nanoplastics in aquatic environments: Aggregation, deposition, and enhanced contaminant transport. Environmental Science \& Technology, 52(4), 1704-1724.

Allen, R., Jarvis, D., Saphyer, S., \& Mills, C. (2012). Entanglement of grey seals Halichoerus grypus at a haul out site in Cornwall, UK. Marine Pollution Bulletin, 64(12), 2815- 2819.

Almeda, R., Wambaugh, Z., Chai, C., Wang, Z., Liu, Z., \& Buskey, E. J. (2013). Effects of crude oil exposure on bioaccumulation of polycyclic aromatic hydrocarbons and survival of adult and larval stages of gelatinous zooplankton. PloS one, 8(10).

Andrady, A. L. (2011). Microplastics in the marine environment. Marine Pollution Bulletin, 62(8), 1596-1605.

Arcadis (2014). Marine Litter study to support the establishment of an initial quantitative headline reduction target. European Commission DG Environment Project number BE0113.000668, URL: http:// ec.europa.eu/environment/marine/goodenvironmental-status/descriptor-10/pdf/ final_report.pdf

Barboza, L. G. A., \& Gimenez, B. C. G. (2015). Microplastics in the marine environment: Current trends and future perspectives. Marine Pollution Bulletin, 97(1-2), 5-12.

Barboza, L. G. A., Vethaak, A. D., Lavorante, B. R., Lundebye, A. K., \& Guilhermino, L. (2018). Marine microplastic debris: An emerging issue for food security, food safety and human health. Marine Pollution Bulletin, 133, 336-348.

Barnes, D. K., Galgani, F., Thompson, R. C., \& Barlaz, M. (2009). Accumulation and fragmentation of plastic debris in global environments. Philosophical Transactions of the Royal Society B: Biological Sciences, 364(1526), 1985-1998.

Bawuro, A. A., Voegborlo, R. B., \& Adimado, A. A. (2018). Bioaccumulation of heavy metals in some tissues of fish in Lake Geriyo, Adamawa State, Nigeria. Journal of environmental and public health, 2018.

Belgian Platform on Earth Observation. (2009). Marine Pollution. https://eo.belspo.be/en/ marine-pollution

Betts, K. (2008). Why small plastic particles may pose a big problem in the oceans.

Bilkovic, D. M., Havens, K., Stanhope, D., \& Angstadt, K. (2014). Derelict fishing gear in Chesapeake Bay, Virginia: Spatial patterns and implications for marine fauna. Marine Pollution Bulletin, 80(1-2), 114-123.

Bleier, A. (2018). Tackling Water Pollution: Marina Trash Skimmer ${ }^{\circledR}$. Retrieved March 11, 2020, from http://www. marinatrashskimmer.com/

Börger, T., Hattam, C., Burdon, D., Atkins, J. P., \& Austen, M. C. (2014). Valuing conservation benefits of an offshore marine protected area. Ecological Economics, 108, 229-241. 
Boucher, J., \& Friot, D. (2017). Primary microplastics in the oceans: A global evaluation of sources. Gland, Switzerland: IUCN.

Bråte, I. L. N., Blázquez, M., Brooks, S. J., \& Thomas, K. V. (2018). Weathering impacts the uptake of polyethylene microparticles from toothpaste in Mediterranean mussels (M. galloprovincialis). Science of the Total Environment, 626, 1310-1318.

Bråte, I. L. N., Eidsvoll, D. P., Steindal, C. C., \& Thomas, K. V. (2016). Plastic ingestion by Atlantic cod (Gadus morhua) from the Norwegian coast. Marine Pollution Bulletin, 112(1-2), 105-110.

Broek, H. van der. (2018, March 9). Waste Canals Amsterdam Recycled into Sustainable Furniture. Retrieved March 11, 2020, from https://www.whatsorb.com/waste/ waste-canals-in-amsterdam-recycled-intosustainable-furniture

Bunghez, C. L. The importance of tourism to a destination's economy. (2016). Journal of Eastern Europe Research in Business \& Economics, 1-9.

Butterworth, A., \& Clegg, I. (2012). Untangled, marine debris: A global picture of the impact on animal welfare and of animalfocused solutions, WSAP.

Carney Almroth, B., \& Eggert, H. (2019). Marine plastic pollution: Sources, impacts, and policy issues. Review of Environmental Economics and Policy.

Carr, S. (2019, May 10). What is marine plastic pollution costing us? The impacts of marine. Retrieved March 12, 2020, from https:// meam.openchannels.org/news/skimmermarine-ecosystems-and-management/ what-marine-plastic-pollution-costing-usimpacts

Chislock, M. F., Doster, E., Zitomer, R. A., \& Wilson, A. E. (2013). Eutrophication: Causes, consequences, and controls in aquatic ecosystems. Nature Education Knowledge, 4(4), 10.
Compa, M., Ventero, A., Iglesias, M., \& Deudero, S. (2018) Ingestion of microplastics and natural fibres in Sardina pilchardus (Walbaum, 1792) and Engraulis encrasicolus (Linnaeus, 1758) along the Spanish Mediterranean coast. Mar Pollut Bull, 128, 89-96.

Davis, J. J., \& Foster, R. F. (1958). Bioaccumulation of radioisotopes through aquatic food chains. Ecology, 530-535.

De-la-Torre, G. E. (2019). Microplastics: An emerging threat to food security and human health. Journal of Food Science and Technology, 1-8.

Devriese, L. I., van der Meulen, M. D., Maes, T., Bekaert, K., Paul-Pont, I., Frère, L., \& Vethaak, A. D. (2015). Microplastic contamination in brown shrimp (Crangon crangon, Linnaeus 1758) from coastal waters of the Southern North Sea and Channel area. Marine Pollution Bulletin, 98(1-2), 179-187.

Directorate-General for Maritime Affairs and Fisheries (European Commission). (2019). The EU blue economy report 2019. EU publications.

Efimova, I., Bagaeva, M., Bagaev, A., Kileso, A., \& Chubarenko, I. P. (2018). Secondary microplastics generation in the sea swash zone with coarse bottom sediments: Laboratory experiments. Frontiers in Marine Science, 5, 313.

Engler, R. E. (2012). The complex interaction between marine debris and toxic chemicals in the ocean. Environmental Science \& Technology, 46(22), 12302-12315.

European Commission. (2012). Blue Growth Study-Scenarios and drivers for Sustainable Growth from the Oceans, Seas and Coasts, Retrieved from: https://webgate. ec.europa.eu/maritimeforum/system/files/ Blue $\% 20$ Growth $\% 20$ Final $\% 20$ Report $\% 20$ 13092012.pdf

Fanshawe, T., \& Everard, M. (2002). The impacts of marine litter. Marine Pollution 
Monitoring Management Group, Report of the Marine Litter Task Team (MaLiTT) May.

Fendall, L. S., \& Sewell, M. A. (2009). Contributing to marine pollution by washing your face: Microplastics in facial cleansers. Marine Pollution Bulletin, 58(8), 1225-1228.

Food and Agriculture Organization of the United Nations (FAO). (2017). Microplastics in fisheries and aquaculture - Status of knowledge on their occurrence and implications for aquatic organisms and food safety. Rome.

Food and Agriculture Organization of the United Nations (FAO). (2018). The State of World Fisheries and Aquaculture 2018 - Meeting the sustainable development goals. Rome.

Fossi, M. C., Coppola, D., Baini, M., Giannetti, M., Guerranti, C., Marsili, L., ... \& Clò, S. (2014). Large filter feeding marine organisms as indicators of microplastic in the pelagic environment: the case studies of the Mediterranean basking shark (Cetorhinus maximus) and fin whale (Balaenoptera physalus). Marine Environmental Research, 100, 17-24.

Frey, O. T., \& De Vogelaere, A. (2014). A review of resource management strategies for protection of seamounts.

Galgani, F., Hanke, G., Werner, S., Oosterbaan, L., Nilsson, P., Fleet, D., \& Scoullos, M. (2013). Guidance on monitoring of marine litter in European Seas. Publications Office of the European Union.

GESAMP (2016). "Sources, fate and effects of microplastics in the marine environment: Second phase assessment part one". Kershaw P.J. and Rochman, C. (Eds.), (IMO/FAO/UNESCO IOC/UNIDO/WMO/ IAEA/UN/UNEP/UNDP Joint Group of Experts on the Scientific Aspects of Marine Environmental Protection). Rep.Stud. GESAMP.
Geyer, R., Jambeck, J. R., \& Law, K. L. (2017). Production, use, and fate of all plastics ever made. Science Advances, 3(7), e1700782.

Gilardi, K., Carlson-Bremer, D., June, J., Antonelis,K., Broadhurst, G. \& Cowan, T. (2010). Marine species mortality in derelict fishing nets in Puget Sound, WA, and the cost/benefits of derelict net removal. Marine Pollution Bulletin, 690, 376-382

Godlee, F., Walker, A. (1991). Importance of a healthy environment. British Medical Journal, 303, 1124-1126

Haegerbaeumer, A., Mueller, M. T., Fueser, H., \& Traunspurger, W. (2019). Impacts of micro-and nano-sized plastic particles on benthic invertebrates: A literature review and gap analysis. Frontiers in Environmental Science, 7, 17.

Hahladakis, J. N., Velis, C. A., Weber, R., Iacovidou, E., \& Purnell, P. (2018). An overview of chemical additives present in plastics: Migration, release, fate and environmental impact during their use, disposal and recycling. Journal of Hazardous Materials, 344, 179-199.

Hall, C. M. (2000). Tourism planning: Policies, processes and relationships, Harlow: Prentice Hall.

Hall, C. M., \& Page, S. J. (2014). The geography of tourism and recreation: Space, place and environment (4th ed.). London: Routledge.

Hammer, J., Kraak, M. H., \& Parsons, J. R. (2012). Plastics in the marine environment: The dark side of a modern gift. In Reviews of environmental contamination and toxicology (pp. 1-44). New York, NY: Springer.

Hoegh-Guldberg, O. (2015). Reviving the ocean economy: The case for action.

Iñiguez, M. E., Conesa, J. A., \& Fullana, A. (2016). Marine debris occurrence and treatment: A review. Renewable and Sustainable Energy Reviews, 64, 394-402. 
International Maritime Organization (IMO). (N.D.). IMO Profile-Overview. Retrieved from: https://business.un.org/en/entities/13 \#overview

Jambeck, J. R., Geyer, R., Wilcox, C., Siegler, T. R., Perryman, M., Andrady, A., \& Law, K. L. (2015). Plastic waste inputs from land into the ocean. Science, 347(6223), 768771 .

Jang, Y. C., Hong, S., Lee, J., Lee, M. J., \& Shim, W. J. (2014). Estimation of lost tourism revenue in Geoje Island from the 2011 marine debris pollution event in South Korea. Marine Pollution Bulletin, 81(1), 49-54.

Jobstvogt, N., Watson, V., \& Kenter, J. O. (2014). Looking below the surface: The cultural ecosystem service values of UK marine protected areas (MPAs). Ecosystem Services, 10, 97-110.

Kelly, B. C., Ikonomou, M. G., Blair, J. D., Morin, A. E., \& Gobas, F. A. (2007). Food web-specific biomagnification of persistent organic pollutants. Science, 317(5835), 236-239.

Kershaw, P. J. (2016). Marine plastic debris and microplastics-Global lessons and research to inspire action and guide policy change.

Keswani, A., Oliver, D. M., Gutierrez, T., \& Quilliam, R. S. (2016). Microbial hitchhikers on marine plastic debris: Human exposure risks at bathing waters and beach environments. Marine Environmental Research, 118, 10-19.

Langenbach, T. (2013). Persistence and bioaccumulation of persistent organic pollutants (POPs). In Applied bioremediation-active and passive approaches (p. 307). Rijeka: InTech.

Laville, S., \& Taylor, M. (2017). A million bottles a minute: World's plastic binge as dangerous as climate change. The Guardian.

Lee, H., Chang, S., Kim, S-K., \& Kwon, J-H. (2017). Fugacity analysis of polycyclic aromatic hydrocarbons between microplastics and seawater. Ocean Science Journal, DOI: 10.1007/s12601-017-0004-9

Lee, J., Lee, J. S., Jang, Y. C., Hong, S. Y., Shim, W. J., Song, Y. K., ... \& Hong, S. (2015). Distribution and size relationships of plastic marine debris on beaches in South Korea. Archives of Environmental Contamination and Toxicology, 69(3), 288-298.

Letcher, T. M., \& Vallero, D. A. (2019). Waste: $A$ handbook for management. Academic Press.

Li, W. C., Tse, H. F., \& Fok, L. (2016). Plastic waste in the marine environment: A review of sources, occurrence and effects. Science of the Total Environment, 566, 333-349.

Lu, L., Luo, T., Zhao, Y., Cai, C., Fu, Z., \& Jin, Y. (2019). Interaction between microplastics and microorganism as well as gut microbiota: A consideration on environmental animal and human health. Science of the Total Environment.

Lyons, Y., Su, T. L., \& Neo, M. L. (2019). A review of research on marine plastics in Southeast Asia.

Lusher, A. L., Mchugh, M., \& Thompson, R. C. (2013). Occurrence of microplastics in the gastrointestinal tract of pelagic and demersal fish from the English Channel. Marine Pollution Bulletin, 67(1-2), 94-99.

MacArthur, E. (2016). The new plastics economy: Rethinking the future of plastics \& Catalysing action. Retrieved from: https://www.ellenmacarthurfoundation. org/assets/downloads/publications/NPECHybrid_English_22-11-17_Digital.pdf

Marine Review of Marine Casualties. (2015). Annual Overview of Marine Casualties and Incidents 2015, Retrieved from: http:// www.emsa.europa.eu/news-a-press-centre/ external-news/item/2551-annual-overviewof-marine-casualties-and-incidents-2015. html

Mathalon, A., \& Hill, P. (2014). Microplastic fibers in the intertidal ecosystem surrounding 
Halifax Harbor, Nova Scotia. Marine Pollution Bulletin, 81(1), 69-79.

McIlgorm, A., Campbell, H. F., \& Rule, M. J. (2011). The economic cost and control of marine debris damage in the Asia-Pacific region. Ocean \& Coastal Management, 54(9), 643-651.

Moore, C. J. (2008). Synthetic polymers in the marine environment: A rapidly increasing, long-term threat. Environmental Research, 108(2), 131-139.

Mortillaro, N. (2017). Humans have produced 8.3 billion tonnes of plastic, researchers say [online]. CBC News, 19 July. Available from: http://www.cbc.ca/amp/1.4210279 [Accessed 12 January 2018].

Mouat, J., Lozano, R. L. \& Bateson, H. (2010). Economic Impacts of marine litter. KIMO International, 105. Retrieved November 29, 2013 from http://www.seas-at-risk. org/1 mages/Economic\%20impacts $\% 20$ of $\% 20$ marine $\% 20$ litter\%20KIMO.pdf.

Moy, K., Neilson, B., Chung, A., Meadows, A., Castrence, M., Ambagis, S., \& Davidson, K. (2018). Mapping coastal marine debris using aerial imagery and spatial analysis. Marine Pollution Bulletin, 132, 52-59.

Naeem, S., Chazdon, R., Duffy, J. E., Prager, C., \& Worm, B. (2016). Biodiversity and human well-being: An essential link for sustainable development. Proceedings of the Royal Society B: Biological Sciences, 283(1844).

Naidoo, R. (2015). Should seas have standing?: A critical study of plastic marine debris and pollution laws in international and South African law (Doctoral dissertation).

NOWPAC MERRAC (Northwest Pacific Action Plan-Marine Environmental Emergency Preparedness and Response Regional Activity Centre). (2013). Negative Impacts of Marine Litter in the NOWPAP Region: Case Studies.
Ocean Conservancy. (2018, October 29). Trash Free Seas Alliance ${ }^{\circledR}$ Members Announce \$100 Million Investment to Fight Ocean Plastic Pollution, 500,000 Tons of Virgin Plastic Eliminated from Products and Packaging. Retrieved March 12, 2020, from https://oceanconservancy.org/news/trashfree-seas-alliance-members-announce-100million-investment-fight-ocean-plasticpollution-500000-tons-virgin-plasticeliminated-products-packaging/.

Organization for Economic Co-operation and Development (OEDC). (2016). The trillion dollar ocean, Retrieved from: http:// oecdinsights.org/2016/04/27/the-trilliondollar-ocean/

Pandey, P. K., Kass, P. H., Soupir, M. L., Biswas, S., \& Singh, V. P. (2014). Contamination of water resources by pathogenic bacteria. Amb Express, 4(1), 51.

Pham, C. K., Ramirez-Llodra, E., Alt, C. H., Amaro, T., Bergmann, M., Canals, M., \& Huvenne, V. A. (2014). Marine litter distribution and density in European seas, from the shelves to deep basins. PloS One, 9(4).

Philipp, R. (1992). Environmental quality objectives and their relationship to health indicators. Biologist, 39(1), 34.

Plastic Litter Project 2018. (2018). Drone Mapping and Satellite Testing for Marine Plastic on Aegean Sea. Retrieved March 11, 2020, from https://mrsg.aegean. $\mathrm{gr} /$ ?content $=\&$ nav $=55$

PlasticsEurope. (2019). PlasticsEuropeThe facts 2019. Retrieved March 6, 2020, from https://www.plasticseurope. org/application/files/9715/7129/9584/ FINAL_web_version_Plastics_the_ facts2019_14102019.pdf

Rees, G., \& Bartram, J. (2002). Monitoring bathing waters: A practical guide to the design and implementation of assessments and monitoring programmes. CRC Press. 
Renzi, M., Guerranti, C., \& Blašković, A. (2018). Microplastic contents from maricultured and natural mussels. Marine Pollution Bulletin, 131, 248-251.

Rist, S., Carney Almroth B., Hartmann, N. B., \& Karlsson, T. M. (2018) A critical perspective on early communications concerning human health aspects of microplastics. Science of the Total Environment, 626, 720-726, http:// dx.doi.org/10.1016/j.scitotenv.2018.01.092

Scheld, A. M., Bilkovic, D. M., \& Havens, K. J. (2016). The dilemma of derelict gear. Scientific Reports, 6, 19671.

Sheppard, C. (2018). World seas: An environmental evaluation: Volume III: Ecological issues and environmental impacts. Academic Press.

Stefatos, A., Charalampakis, M., Papatheodorou, G., \& Ferentinos, G. (1999). Marine debris on the seafloor of the Mediterranean Sea: Examples from two enclosed gulfs in Western Greece. Marine Pollution Bulletin, 38(5), 389-393.

Sun, X., Li, Q., Zhu, M., Liang, J., Zheng, S., \& Zhao, Y. (2017). Ingestion of microplastics by natural zooplankton groups in the Northern South China Sea. Marine Pollution Bulletin, 115, https://doi. org/10.1016/j.marpolbul.2016.12.004

Takehama, S. (1990). Estimation of damages to fishing vessels caused by marine debris, based on insurance statistics. Proceedings of the Second International Conference on Marine Debris, Honolulu, Hawaii, 2-7 April 1989, 792-809.

The Ocean Cleanup. (2019). Rivers. Retrieved March 6, 2020, from https:// theoceancleanup.com/rivers/

Trash Hero. (2018). Trash Hero World Annual Report 2017. Retrieved March 12, 2020, from https://trashhero.org/wp-content/ uploads/2018/08/Trash-Hero-WorldAnnual-Report-2017.pdf.

UNDP. (2015). Goal 14: Life below water. Retrieved March 6, 2020, from https:// www.undp.org/content/undp/en/home/ sustainable-development-goals/goal-14life-below-water.html

UNEP (2014b). Valuing plastics: The business case for measuring, managing and disclosing plastic use in the consumer goods industry.

UNEP (2015a). Biodegradable Plastics and Marine Litter. Misconceptions, concerns and impacts on marine environments. United Nations Environment Programme (UNEP), Nairobi.

UNEP (2015b). Global waste management outlook. UNEP \& ISWA, 346pp.

UNEP (2016b in press). Marine litter A modelling study. United Nations Environment Programme (UNEP), Nairobi.

UNEP (2016c in press). Marine litter: Socio-economic study. United Nations Environment Programme (UNEP), Nairobi.

UN News. (2014). Plastic waste causes $\$ 13$ billion in annual damage to marine ecosystems, says UN agency, Retrieved from: https://news.un.org/en/ story/2014/06/471492-plastic-wastecauses-13-billion-annual-damage-marineecosystems-says-un-agency

Valle-Levinson, A., \& Swanson, R. L. (1991). Wind-induced scattering of medically-related and sewage-related floatables. Marine Technology Society Journal MTSJBB, 25(2).

Vann R. D., \& Lang, M. A. (2010). Recreational Diving Fatalities Workshop Proceedings. Retrieved from: https://www. diversalertnetwork.org/files/Fatalities Proceedings.pdf

Verschoor, A., De Poorter, L., Dröge, R., Kuenen, J., \& de Valk, E. (2016). Emission of microplastics and potential mitigation measures: Abrasive cleaning agents, paints and tyre wear.

Vethaak, A. D., \& Leslie, H. A. (2016). Plastic debris is a human health issue. 
Van Cauwenberghe, L., \& Janssen, C. R. (2014). Microplastics in bivalves cultured for human consumption. Environmental Pollution, 193, 65-70.

Vandermeersch, G., Van Cauwenberghe, L., Janssen, C. R., Marques, A., Granby, K., Fait, G., ... \& Devriese, L. (2015). A critical view on microplastic quantification in aquatic organisms. Environmental Research, 143, 46-55.

Worm, B., Lotze, H. K., Jubinville, I., Wilcox, C., \& Jambeck, J. (2017). Plastic as a persistent marine pollutant. Annual Review of Environment and Resources, 42, 1-26.

Wright, S. L., Thompson, R. C., \& Galloway, T. S. (2013). The physical impacts of microplastics on marine organisms: A review. Environmental Pollution, 178, 483492.

Zitko, V., \& Hanlon, M. (1991). Another source of pollution by plastics: Skin cleaners with plastic scrubbers. Marine Pollution Bulletin, 22(1), 41-42. 